\title{
Efficiency versus Sovereignty: Delegation to the UN Secretariat in Peacekeeping
}

Citation for published version (APA):

Dijkstra, H. (2012). Efficiency versus Sovereignty: Delegation to the UN Secretariat in Peacekeeping. International Peacekeeping, 19(5), 581-596. https://doi.org/10.1080/13533312.2012.721993

Document status and date:

Published: 22/11/2012

DOI:

10.1080/13533312.2012.721993

Document Version:

Accepted author manuscript (Peer reviewed / editorial board version)

\section{Document license:}

Unspecified

\section{Please check the document version of this publication:}

- A submitted manuscript is the version of the article upon submission and before peer-review. There can be important differences between the submitted version and the official published version of record.

People interested in the research are advised to contact the author for the final version of the publication, or visit the DOI to the publisher's website.

- The final author version and the galley proof are versions of the publication after peer review.

- The final published version features the final layout of the paper including the volume, issue and page numbers.

Link to publication

\footnotetext{
General rights rights.

- You may freely distribute the URL identifying the publication in the public portal. please follow below link for the End User Agreement:

www.umlib.nl/taverne-license

Take down policy

If you believe that this document breaches copyright please contact us at:

repository@maastrichtuniversity.nl

providing details and we will investigate your claim.
}

Copyright and moral rights for the publications made accessible in the public portal are retained by the authors and/or other copyright owners and it is a condition of accessing publications that users recognise and abide by the legal requirements associated with these

- Users may download and print one copy of any publication from the public portal for the purpose of private study or research.

- You may not further distribute the material or use it for any profit-making activity or commercial gain

If the publication is distributed under the terms of Article $25 \mathrm{fa}$ of the Dutch Copyright Act, indicated by the "Taverne" license above, 


\title{
Efficiency versus Sovereignty: Delegation to the UN Secretariat in Peacekeeping
}

\author{
Hylke Dijkstra \\ This is the electronic version of an article published in: \\ International Peacekeeping 19(5), 2012: pp. 581-596. \\ DOI: $10.1080 / 13533312.2012 .721993$
}

\begin{abstract}
This article analyses why the UN's members delegate resources to the UN Secretariat in the sensitive field of peacekeeping. It argues that the Secretariat can carry out planning and implementation functions more efficiently, but that the states remain wary of potential sovereignty loss. Through a mixed methods approach, the article provides evidence for such functional logic of delegation, but shows that it only applies from the late 1990s on. The change in approach of states towards delegation can be explained by feedback from the dramatic failures of peacekeeping in Bosnia and Herzegovina, Rwanda and Somalia.
\end{abstract}

Key words DPKO, peacekeeping, UN Secretariat, United Nations

The UN Secretariat has become a considerable actor in international security. In 2012 it employed more than 600 officials in New York, who are directly responsible for the planning and conduct of peacekeeping missions. ${ }^{1}$ The Department of Peacekeeping Operations (DPKO), for example, has sizable offices dealing with operations, rule of law and security institutions and military affairs. The Department of Field Support (DFS) handles personnel and budgetary questions as well as logistics, communication and training. The situation has not always been thus. When the Berlin Wall came down in 1989, there were only a dozen officials in the Secretariat working on peacekeeping.

Why have states delegated functions and corresponding resources to the Secretariat in the sensitive area of peacekeeping? ${ }^{2}$ This article provides a functionalist answer by showing that delegation is the result of increasing demands for efficient UN peacekeeping after the Cold War. While member states deployed less than 10,000 troops in 1989, nearly 100,000 uniformed personnel were serving in peacekeeping missions in 2012. The mandate and intensity of peacekeeping has changed as well. Operations during the Cold War are often classified as 'first generation' peacekeeping, whereas contemporary missions are described as 'second' or even 'third generation' operations. ${ }^{3}$ To efficiently handle these increasing demands of peacekeeping, states have delegated planning and conduct functions to the Secretariat.

Delegation has, however, not been automatic; nor has it been purely the effect of the changing demands. Until the mid-1990s, states avoided delegation in spite of a recognition that delegation could result in efficiency gains. It was only after the dramatic failures of UN peacekeeping efforts in Bosnia and Herzegovina, Rwanda and Somalia in 1994-95, that states started to upgrade the Secretariat. Institutional failure created, in this respect, a considerable 
'feedback loop' in terms of delegation decisions. The Brahimi Report of 2000, in particular, initiated a modus operandi, in which the resources of the Secretariat mirrored the actual activity in terms of deployments. For reasons of control, however, the Secretariat remained understaffed compared to other security organizations.

This article starts by introducing the literature on delegation in international organizations. It stresses that delegation should be seen as a process, in which states weigh anticipated efficiency gains against sovereignty loss. The article subsequently provides empirical data about the Secretariat's resources and tests the extent to which delegation follows peacekeeping activity. It shows that the number of staff members in New York strongly correlates to the number of deployed troops after the mid-1990s. The article continues by qualitatively assessing why Member States delegate in the context of the An Agenda for Peace (1992), and the Brahimi Report and Peace Operations 2010 (2005-2010). It confirms that delegation occurs as a result of increases in troop deployments. Initiatives that provide the Secretariat with additional functions, however, typically run into sovereignty costs.

\section{Delegation in International Organizations}

According to the rationalist literature, two or more states delegate functions to a body in an international organization - such as the Secretariat - when they expect the benefits of delegation to outweigh the costs. ${ }^{4}$ In the simplest delegation model, certain functions can either be carried out by the members domestically or by an international body. If the they expect an international body to perform functions better and/or cheaper, they may choose to delegate. In other words, they 'face the choice of whether to perform the desired functions "in-house", or to "outsource" them'. It is therefore important to identify which functions can be delegated in peacekeeping.

First, however, it is necessary to remark on delegation decision-making. In much of the literature, the process of delegation is simplified to a single moment in time when states make cost benefit calculations and take a decision. In reality, of course, delegation is not a one off affair. It is better to conceptualize delegation as a 'dynamic and interactive [process] subject to bargaining and revision by [states]'. 6 They make delegation decisions at subsequent moments and use feedback from previous delegation rounds. Feedback helps them to better understand the effects of delegation, thereby reducing the uncertainty surrounding their delegation decisions. An incremental approach to delegation has the benefit of limiting unintended consequences.

\section{Efficiency Gains}

There are many different functions that states can delegate to international bodies in order to reach efficiency gains. This article focuses on the two most relevant for the UN Secretariat in peacekeeping: the formulation of operations (planning) and their implementation (conducting). Needless to say, the Secretariat also carries out a range of conference management tasks and provides negotiation support to states. Moreover, Under the UN Charter (Art.99) the SecretaryGeneral has a formal role in agenda setting. Yet the two substantive functions perhaps matter most and will therefore be the topic of this article. For the planning and conduct of peacekeeping operations, this section will show that states can potentially reach efficiency gains by outsourcing certain functions to the Secretariat.

The planning of peacekeeping operations starts after the possibility of an operation is first raised, and ends with the decision of states to (not) deploy. It typically involves the preparation of alternative peacekeeping scenarios and a calculation of their requirements and effects. ${ }^{7}$ This is a demanding exercise. It requires, inter alia, a combination of detailed information about the situation in the field and considerable content expertise (military, political, logistical). States can choose to carry out these planning functions themselves. They can decide to gather all relevant information 
through their national channels, prepare scenarios in their own ministries, and finally go collectively into a conclave in order to choose the best option ('war by committee' model). The alternative is to outsource these functions.

Centralized planning for peacekeeping holds considerable advantages. First, outsourcing implies that the states no longer have to carry out the functions themselves and avoids duplication. Second, by centralizing functions within the Secretariat, states benefit from continuity, specialization gains, the accumulation of expertise and institutional learning. ${ }^{8}$ Third, peacekeeping scenarios prepared by the Secretariat are likely to be more neutral than the ones proposed by states. ${ }^{9}$ Fourth, and relatedly, there is a need for professionalism in military planning. It is therefore helpful to put planning outside the political realm. ${ }^{10}$ In short, there are several incentives for states to delegate planning functions to the Secretariat in support of their operations.

There are equally potential benefits to centralizing the conduct of operations. To being with there exists the sacrosanct demand for 'unity of command' in military affairs to ensure that hierarchical lines are clear. Ideally, peacekeepers in the field thus either report through state or UN channels. ${ }^{11}$ The former is less efficient, as peacekeeping operations are almost always multinational. Parallel command and control structures form a tremendous obstacle in carrying out a joint operation. Even when Troop Contributing Counctries opt for national command structures, they still need coordination mechanisms. If they choose integrated command and control instead, this normally requires a command centre close to decision-making processes in New York and appropriate structures in the field.

In addition to command and control, there are crucial peacekeeping support functions, ranging from strategic facilitation (such as field hospitals, satellite imagery and logistics) to administrative tasks (personnel and financial management, procurement and contacts with the host states). Centralization of these support functions can yield many of the same benefits as the centralized planning. It allows for continuity and the accumulation of expertise. Moreover centralization can create considerable clarity in the field if, for example, all troops wear blue helmets, obey the same rules of engagement, and are protected under the same Status of Forces Agreement. Furthermore, in the UN context, different states authorize missions, finance them and contribute troops. ${ }^{12}$ From an efficiency perspective this creates further incentives for the centralization of support functions.

\section{Sovereignty Costs}

States can achieve efficiency gains by delegating various functions and corresponding resources to the Secretariat. Delegation, however, also involves costs, of which sovereignty loss is the most important. ${ }^{13}$ David Epstein and Sharyn O'Halloran measure sovereignty costs 'as the distance between the policy that a country would implement if it were not a member of the international organization and the policy that it enacts once it has joined' ${ }^{14}$ Sovereignty costs are most relevant to international organizations involving delegation. They are high 'when international arrangements impinge on the relations between a state and its citizens or territory' and low if agreements only put limits on state behaviour in specific circumstances. ${ }^{15}$

Since sovereignty costs are closely related to delegation, one can best conceptualize the process of delegation as a trade off between the anticipated efficiency gains and the anticipated sovereignty costs. This implies that delegation results in sub-optimal outcomes, because the ultimate efficiency gains are never fully achieved. ${ }^{16}$ First, under 'bounded rationality', states cannot completely predict the long term effects of their actions. ${ }^{17}$ Risk adverse actors, however, tend to know that their foresight is limited. If there is uncertainty concerning the anticipated costs and benefits, states are likely to be wary of delegation (or delegate incrementally). Second, if they anticipate that sanctioning or taking back functions will be difficult given their own divisions on institutional design, they may decide against delegation in the first place. ${ }^{18}$ In other words, the risk 
of excessive sovereignty costs puts a major brake on delegation.

Yet even in cases where delegation occurs, states install control mechanisms to limit sovereignty costs. ${ }^{19}$ At an elementary level, few international bodies have the autonomy to set their own budgets or rewrite their constitutional rules. Most are also restricted in recruiting their personnel. Temporary appointments and secondments at the lower levels and agent selection in the higher echelons of international bodies are omnipresent. Moreover, state committees (such as the Security Council) inspect the work of international bodies and often retain ultimate decision-making power. States also operate domestic 'shadow' bureaucracies to avoid dependence on international bodies. ${ }^{20}$ The trouble with these control mechanisms is that they are costly. They also often undermine the efficiency rationale that initially led to delegation.

\section{Delegation: Overall Trends}

There exists a strong functional logic to rationalist theories of delegation. For a peacekeeping operation states want to deploy their troops collectively. This leads to a demand for planning and implementation functions, with states anticipating that the Secretariat can carry out these functions more efficiently. They therefore delegate these functions and provide the Secretariat with the necessary resources. It follows that evolution in the activities of states will also likely affect the delegation of resources. According to rationalist theories, the resources of secretariats are therefore a function of the activity of international organizations. This section shows that changes in peacekeeping activity are indeed the driving explanatory factor behind the centralization of resources.

As an indicator for peacekeeping activity, this article uses the number of deployed troops by states under the UN flag (independent variable). ${ }^{21}$ This is a more precise indicator than, for example, the number of operations which are of varying size and therefore do not have common functional requirements. The article uses the number of Secretariat officials in New York as an indicator for the resources delegated by states (dependent variable). This is a better indicator than the Secretariat budget, which is fragmented and subject to inflation. This leads to the following hypothesis: if UN troop deployments increase or decrease, the number of Secretariat officials increases or decreases accordingly.

The data is available from open sources: monthly data on troop deployments (1990-2011) is on the UN website; ${ }^{22}$ data on Secretariat officials (1993-2011) is in the annual report on the 'Composition of the Secretariat'. ${ }^{23}$ The analysis here uses data for 'professional and higher categories' in the DPKO and DFS and excludes technical support staff, such as secretaries. To compare the data on troop deployments and staff members, troop deployments are annualized through the median. 


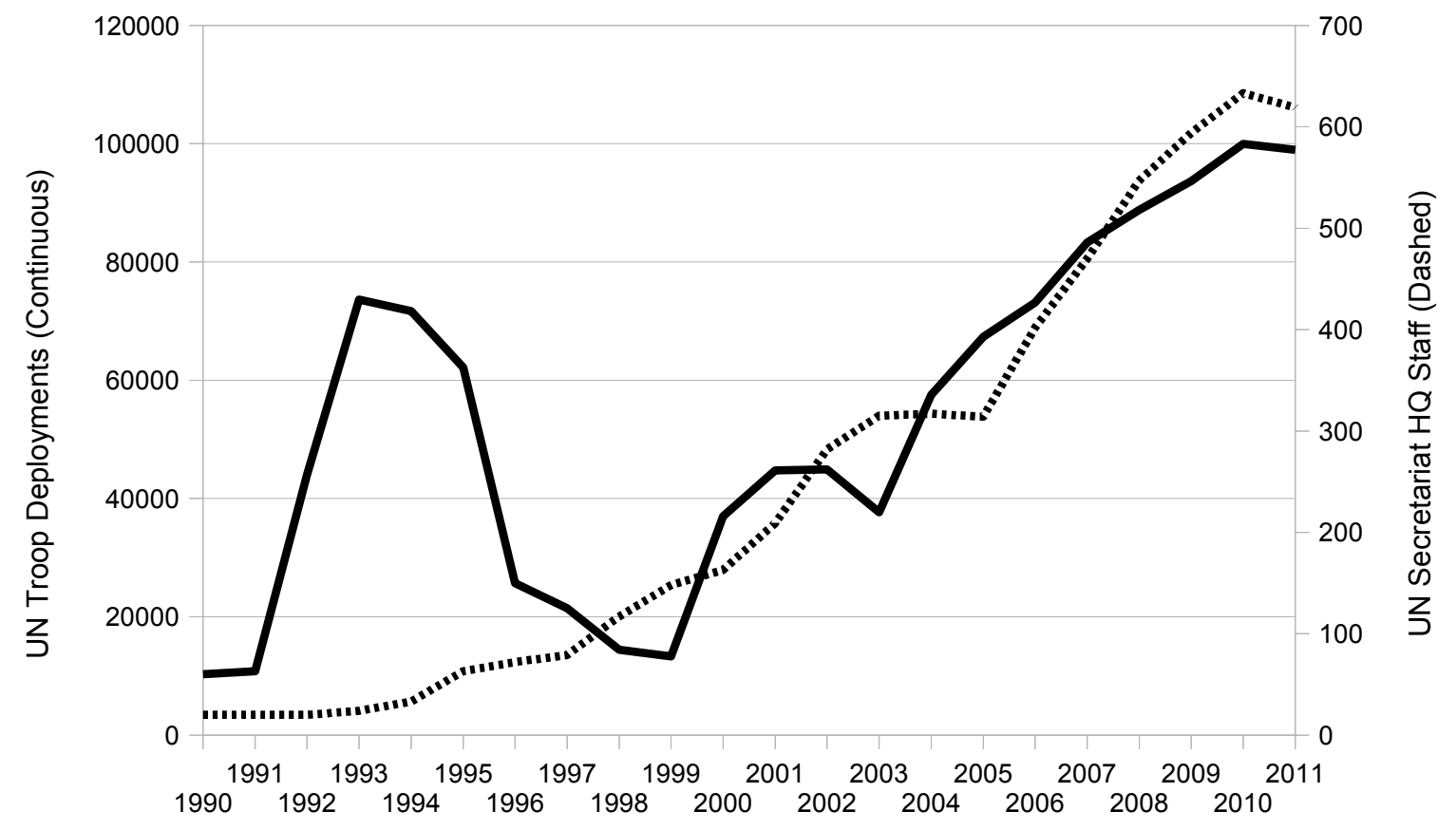

Figure 1: development of troop deployments and headquarters staff over time

Figure 1 provides an overview of troop deployments and Secretariat officials over time. A strong relationship between activity and the delegation of resources is evident, but only for the period from the late 1990s. There was no such relationship before the mid-1990s. Calculating the correlation is not straightforward, however, as the observations are not random. In line with the stated hypothesis, this article analyses 'first differences' by considering the annual changes in troop deployments and the Secretariat officials. It subsequently calculates the correlations between these changes for different periods up until 2010-11, and builds in a control for a 'recruitment delay' of one, two and three years. As Table one shows, a time lag of two years gives the best results. Such a period seems reasonable because states have to negotiate an increase in the Support Account for Peacekeeping, which occurs once a year. Subsequently, new officials need to be recruited.

\begin{tabular}{|l|c|c|c|c|}
\hline Period & $\mathbf{T + 0}$ & $\mathbf{T + 1}$ & $\mathbf{T + 2}$ & $\mathbf{T + 3}$ \\
\hline $1998-99-2010-11$ & -0.21 & 0.2 & 0.71 & -0.09 \\
\hline $1996-97-2010-11$ & -0.1 & 0.2 & 0.7 & -0.03 \\
\hline $1994-95-2010-11$ & 0.11 & 0.36 & 0.48 & 0.04 \\
\hline $1992-93-2010-11$ & 0 & 0.22 & 0.41 & -0.06 \\
\hline $1990-91-2010-11$ & -0.09 & 0.11 & 0.27 & -0.06 \\
\hline
\end{tabular}

Table 1. Overview of correlations between the annual increase in deployments and annual increase in Secretariat officials adjusted for a time lag.

From these empirical results, it is possible to draw several conclusions. They clearly confirm that there is a strong relationship between troop deployments and the number of Secretariat officials. This implies that UN peacekeeping activity determines the resources that states delegate to the Secretariat. ${ }^{24}$ This finding supports the rational theory of delegation that stresses an efficiency 
rationale resulting from functional demands. The main caveat is that the hypothesis is only confirmed for a certain period. From the end of the 1990s there exists a strong correlation (above 0.7). For the whole period (1990-91 until 2010-11), however, there is little correlation between activity and delegation (only 0.27 ).

The approach by states in delegating resources changed during the mid- to late 1990s. As will be shown below, there are two explanations for this. First, 'feedback loops'; the handful of Secretariat officials were incapable of handling the enormous spurt in troop deployments in the early 1990s, and failures in Bosnia and Herzegovina, Rwanda and Somalia. States took this into account when troop deployments started to increase after 1999. Second, 'gratis personnel'; to deal with the increase in peacekeeping, some states sent their own officers to the Secretariat between 1993-98..$^{25}$ These officials were paid for by these individual states and not formally delegated to the Secretariat. It was a third way, in between outsourcing and keeping functions in house, and helps to explain why there was so little formal delegation. ${ }^{26}$

Whereas the anticipated sovereignty costs put a brake on delegation during the early 1990s, the need for efficiency became more prominent from the late 1990s. Nevertheless, it is important not to discount sovereignty costs for the second period, since they may also result in less than functionally optimal delegation. In this respect it is worthwhile comparing other international organizations, such as NATO. While comparing the UN and NATO is problematic, the difference in the ratio between HQ staff and troop deployments is interesting. For example, one report notes a ratio $1: 18$ for NATO and 1:100 for the UN. ${ }^{27}$ In other words, while the number of UN Secretariat officials closely follows deployments, the 'slope' is not very steep in the UN.

\section{Delegation: Process Tracing}

The UN conducted a dozen peacekeeping operations during the Cold War that were supported by a handful of officials in the Office for Special Political Affairs of the Secretary-General. ${ }^{28}$ Afterwards, the deployments increased dramatically. This section studies three instances, during which the requirements for peacekeeping and delegation were explicitly discussed by states. It starts with $A n$ Agenda for Peace (1992) drafted by Secretary-General, Boutros Boutros-Ghali. It continues with the Brahimi Report (2000), which built on the experience of the 1990s and concludes with Peace Operations 2010 (2005-2010). This section examines state discourses regarding delegation decisions. ${ }^{29}$

\section{An Agenda for Peace}

An Agenda for Peace reflected the optimism that accompanied the end of the Cold War because bipolarity was no longer paralysed the work of the Security Council, and the UN had an opportunity to deal with other conflicts through conflict prevention, peacemaking, peacekeeping and peacebuilding. ${ }^{30}$ As the report addressed heads of state and governments, it did not discuss the delegation of functions to the Secretariat in detail, which was left to parallel committees. In these discussions a strong efficiency rationale was put forward for strengthening the Secretariat in accordance with the new ambitions. When implemented, however, it became clear that states were unwilling to delegate additional resources to the Secretariat.

The rapidly increasing importance of peacekeeping led to questions about the Secretariat's resources for the job, with the first discussions occurring already before the sharp increase in deployments in 1992-93. For example the Special Committee on Peacekeeping Operations of June 1991 reported:

In view of the recent dramatic increase in peacekeeping operations and the expansion of their mandates, some delegations expressed concerns at the 
increasing burden on the Secretariat. They wondered whether it had sufficient resources to ensure the effectiveness of the various operational components and stressed the need to consider the possibility of strengthening the Secretariat units concerned. ${ }^{31}$

In January 1992, the Security Council also met for the first time in a 'heads of state and governments' format to discuss the post-Cold War system. It noted that 'peace-keeping tasks have increased and broadened considerably in recent years' and stressed 'the importance of strengthening and improving the United Nations to increase its effectiveness'. Accordingly, it invited the Secretary-General to prepare recommendations for improving 'the capacity of the United Nations for preventive diplomacy, for peacemaking and for peacekeeping', drawing on lessons learned from recent missions in order to recommend ways of making more effective Secretariat planning and operations'. ${ }^{32}$

As deployments increased, calls for delegation became louder. The Special Committee noted in June 1992 that 'the recent sharp rise in demand for United Nations peacekeeping operations had imposed a considerable strain on the Secretariat' and urged further reform 'to handle such operations more effectively and efficiently'. Many states agreed that '[s]ufficient human resources ... were the prerequisite for successful and effective planning, coordination and management of new and ongoing peace-keeping operations'. ${ }^{33}$ Given a convergence in the discussions on effectiveness and the delegation of resources, it is not surprising that the Agenda reflected such points, stressing not only a need for 'effective United Nations command at Headquarters and in the field; and adequate financial and logistic support' but also that '[t]he strength and capability of military staff serving in the Secretariat should be augmented to meet new and heavier requirements' ${ }^{34}$ However, implementation was underwhelming. Establishment of the DPKO in February 1992 was essentially a merger of staff from the Office for Special Political Affairs and Department of Management responsible for peacekeeping support (e.g., logistics). ${ }^{35}$ The total staff did not expand significantly, and when Kofi Annan became Under Secretary-General in the DPKO in March 1993, it 'still operated in an atmosphere of chaos' ${ }^{36}$ He managed to gain a modest staff increase and create a 24-hour situation centre, but was much less successful in other aspects, such as military command. ${ }^{37}$

Due to budgetary pressures, DPKO started accepting 'gratis personnel' paid for completely by contributing states. ${ }^{38}$ They mostly had military expertise and, unlike UN officials, were more easily controlled by their governments. By 1997 over 130 gratis personnel had joined DPKO, almost all from NATO members and related allies. Other states consequently raised questions about geographical balance and representation that favoured the West. The dispute led to General Assembly Resolution 51/243 of 15 September 1997, which discontinued the practice, and DKPO lost its gratis personnel. The Secretariat hoped that gratis personnel would be replaced by permanent posts, which turned out to be wishful thinking. ${ }^{39}$ States no longer saw the need given a decrease in peacekeeping activity after 1995. The dispute exemplified the tension between a Western demand for efficient peacekeeping, on the one hand, and the UN's global representation on the other. The experience of UN peacekeeping in the mid-1990s had a sobering effect on the delegation issue, and after US withdrawal from Somalia, the US was no longer willing to fund any expansion. ${ }^{40}$

Thus, although a need for resource delegation had been recognized in the post- Cold War years and the role of peacekeeping in international security led to strong demands for efficiency, states did not delegate additional resources to the Secretariat. Other than the gratis personnel, only several dozen staff in New York supported almost 80,000 peacekeepers in the field.

\section{The Brahimi Report}


Delegation to the Secretariat became topic of debate again in the context of the Report of the Panel on UN Peace Operations ('Brahimi Report') of 2000 ${ }^{41}$ Essentially three factors provided input to the deliberations. First, candid reports were published on the role of the UN in Bosnia/Srebrenica and Rwanda. ${ }^{42}$ Second, regional organizations had become increasingly responsible for peacekeeping between 1996 and 1998, but they faced many of the same challenges as the UN. ${ }^{43}$ Third, between June and November 1999 the UN started various new operations (Kosovo, East-Timor, Sierra Leone and the Democratic Republic of Congo).

In March 2000 Annan tasked the Panel on UN Peace Operations to 'undertake a thorough review of the United Nations peace and security activities, and to present a clear set of specific, concrete and practical recommendations' ${ }^{44}$ Its work had to be ready before the Millennium Summit in September. The final report was a comprehensive analysis and is still considered a milestone document for UN peacekeeping, addressing, everything from doctrine, strategy and decisionmaking to rapid deployment and headquarters resources, as well as peacekeeping in an information age. ${ }^{45}$ Regarding delegation, the report dealt with structural problems and with immediate requirements resulting from the new deployments which became the driving force behind reform.

The Secretariat had been badly prepared to handle the increase in operations, which took place a couple of months after the gratis seconded officers had left New York. Indeed, the Brahimi Report noted that 'it is clearly not enough to have 32 officers providing military planning and guidance to 27,000 troops in the field, nine civilian police staff to identify, vet and provide guidance for up to 8,600 police, and 15 political desk officers for 14 current operations and two new ones' ${ }^{46}$ Brahimi also presented the headquarters' costs as a percentage of the total peacekeeping budget since the mid-1990s. It showed that while new operations had pushed up the overall budget by 318 per cent between 1998-99 and 2000-01, the budget for the headquarters had only increased by a modest 22 per cent. The shortage of staff meant that 'key personnel have no back-up, no way to cover more than one shift in a day when a crisis occurs six to 12 time zones away except by covering two shifts themselves, and no way to take a vacation, get sick or visit the mission without leaving their backstopping duties largely uncovered'. The report included a table detailing how only five to eight officials supported the four new operations (each with a half billion dollars annual budget). Not surprisingly, the report recommended a substantial increase in resources. ${ }^{47}$ For implementation, DPKO indeed gained 93 additional officials to deal with the new activities, albeit initially less than half of the 214 the Secretariat had proposed. ${ }^{48}$

The report made further observations about the balance between efficiency and sovereignty costs. In noted that 85 per cent of the DPKO budget came from the Support Account for Peacekeeping, which is subject to approval by the member states each year. In this respect, the report noted:

Clearly, DPKO and the other Secretariat offices supporting peacekeeping should expand and contract to some degree in relation to the level of activity in the field, but to require DPKO to rejustify, every year, seven out of eight posts in the Department is to treat it as though it were a temporary creation and peacekeeping a temporary responsibility of the Organization. ${ }^{49}$

The report argued that the situation in which states enjoyed strict control over the resources was sub-optimal: '[Continued] preparedness is essential, even during downturns in field activity, because events are only marginally predictable and staff capacity and experience, once lost, can take a long time to rebuild, as DPKO has painfully learned in the past two years'. The report recommended therefore that peacekeeping became a core UN activity funded through the regular budget. ${ }^{50}$ However, states made no decision and the status quo remained to continue the practice of annual funding DPKO, despite the noted efficiency gains that could be achieved by making jobs more permanent. The desire for control trumped efficiency gains in this instance. 
In addition to the overall question of resources, a debate on the peacekeeping functions of the Secretariat focused on information gathering, analysis and advance planning. The Brahimi Report argued that to engage in effective conflict prevention and peacekeeping, there was a need for 'accumulating knowledge about conflict situations, distributing that knowledge ... generating policy analyses and formulating long-term strategies'. It suggested the establishment of an Information and Strategic Analysis Secretariat (EISAS) with staff coming from various departments. Moreover, 'additional staff would be required to give EISAS expertise that does not exist elsewhere in the system'. ${ }^{51}$ The recommendation was supported by Annan, who wanted to hire 16 new staff members and transfer in 37 others from elsewhere in the UN system. ${ }^{52}$ The establishment of such new analytical capability, however, was blocked by non-aligned, which feared that humanitarian intervention might be used against them. ${ }^{53}$ Consequently, the Secretariat tried halving Annan's proposal, which was also rejected. For many states gathering and analysing conflict data was too sensitive to delegate to the Secretariat, despite the recognition that such capability would make peacekeeping more efficient.

The Brahimi Report had created awareness of the tremendous pressures under which the Secretariat was operating - and so staffing could only be increased through emergency measures. In anticipating excessive sovereignty costs, states did not fundamentally change DPKO's financing or delegate new functions for data gathering and analysis.

\section{Peace Operations 2010}

With the benefit of hindsight, the increase in peacekeeping operations at the end of the 1990s signalled a new departure. In the decade that followed, deployments went up from 37,500 to a peak of 102,000 uniformed personnel. As a result, delegation re-emerged in Peace Operations 2010 (2005-2010), though not centred on a single report as in previous debates. Rather it was a continuous review process, though no less radical, consisting of several documents by the Secretary-General and DPKO/DFS, beginning in 2005. In his implementation report on Brahimi, Annan noted that 'it is now incumbent upon us to set the agenda for the next 5 to 10 years of ... peacekeeping' in the light of the deployment surge. ${ }^{54}$ He suggested five priorities: partnerships, doctrine, people, organization and resources. During 2006, however, deployments kept increasing and this became the main focus of attention in a new Secretary-General's implementation report. ${ }^{55}$

Ban Ki-moon noted that ' $[\mathrm{t}] \mathrm{he}$ increase in the number, scope, size and operational environment challenges for United Nations peace operations has consequences for the way in which field missions are managed and supported by Member States and the Secretariat'. His immediate emphasis was on Secretariat resources, in particular strengthening senior management and having clearer reporting lines. ${ }^{56} \mathrm{He}$ argued on grounds of accountability, an important theme during his campaign for Secretary-General. One suggestion was to take all support functions out of DPKO and create a separate Department of Field Support to allow DPKO to focus exclusively on planning and the command and control of operations. ${ }^{57}$ In this respect the report re-emphasized the unity of command with responsibility for peacekeeping decisions resting with the Under-Secretary-General Peacekeeping Operations. Ban Ki-moon further noted that the Military Division of DPKO was drastically understaffed with only 13 officers handling all operations. ${ }^{58}$

He followed up several months later with a more detailed report. This, second report was extraordinary in its restructuring and specification of responsibilities in various units dealing with peacekeeping. The plea for new resources and the sense of urgency was also stronger than before. The key problem was not only the quantitative growth in deployments, but also a qualitative growth in complexity: 'Security Council mandates have assigned an increasingly wider range of substantive responsibilities to peacekeeping missions over the past several years in such areas as protection of civilians, promotion of the rule of law, support for national efforts in reforming security institutions, child protection and gender'. Ban Ki-moon accordingly suggested 276 new posts for the Secretariat 
in the professional and higher grades..$^{59}$

In addition, he suggested reorganization, noting that:

The reality of global demand for United Nations peacekeeping is that it is no longer tenable to simply add 300 or 400 more posts to the existing [DPKO], which operates with a structure and management capacity designed to deal with a different order of scope and magnitude of field operations and which has remained unchanged since 2002. The senior management of the Department has remained constant ... despite the doubling of the level and increased complexity of peacekeeping activity since then. ${ }^{60}$

Ban Ki-moon proposed organizing the work through three offices: operations; military affairs; and rule of law and security institutions. Regarding the Office of Military Affairs, he published a separate report proposing to more than double the officials. ${ }^{61}$ The states accepted many of the suggestions for reorganization and new senior appointments. However, they did not approve the Secretariat's requested resources. ${ }^{62}$ While any bureaucracy typically asks for more resources than it expects to get, the states again took a minimalist approach to delegation. Despite the demands of complexity, the ratio between deployments and staff remained almost the same.

Finally, during the period of 'Peace Operations 2010', TCCs also reasserted control of functions. For example, when the enhancement of the UN Interim Force in Lebanon (UNIFIL) with European troop contributors was discussed in 2006, France initially insisted on having a French four star general in New York to command the operation. Eventually a compromise was reached with the establishment of a Strategic Military Cell in DPKO consisting mostly of European experts. ${ }^{63}$ This was a clear example of some states were unwilling to yield control over their own troops. It naturally resulted in tensions quite similar to the those concerning gratis personnel. Various other TCCs wondered why European troops deserved professional expertise while their troops had to deal with the overstretched UN officials.

\section{Conclusion}

The UN Secretariat has grown significantly in the peacekeeping sphere since the end of the Cold War. This article has examined why states delegate functions and resources to the Secretariat in this sensitive field. It has put forward a functional explanation of delegation arguing that they can achieve efficiency gains by outsourcing planning and conduct functions. Delegation, however, inevitably involves sovereignty loss and states have tried to balance efficiency and sovereignty. To what extent is this explanation of delegation confirmed by evidence?

The article has shown that since the end of the 1990s, there has been a strong relationship between troop deployments and the number of Secretariat officials, albeit with a two year recruitment delay. This form-follows-function argument of institutional design has to account for sovereignty costs that have been omnipresent. Before the mid-1990s, states typically rejected the delegation of resources and provided their own gratis personnel instead. Moreover, the ratio between staff at the UN headquarters and troops in the field remained very low compared to NATO, and was probably sub-optimal.

These overall trends are supported by detailed process-tracing. The rationale for delegation was clearly the increase in peacekeeping operations. The new missions after 1989 informed the Agenda, those of 1999 provided input for Brahimi, and the surge in the 2000s resulted in Peace Operations 2010. Moreover, the delegation of resources often occurred in an emergency situation to address urgent new demands. Delegation was also often minimal and focused on 'backstopping'. The Secretariat got much less than it asked for. Fundamental and qualitative reform through delegation ran into the political concerns of states. The Support Account for Peacekeeping, through 
which most DPKO/DFS personnel are paid, has to be negotiated on an annual basis; a major obstacle for efficiency, but perfect for control.

A critique of rational choice institutionalism is often that the conclusions seem too obvious. ${ }^{64}$ There exist, however, prominent theories of international organization that suggest other results. Realist scholars typically see international organizations solely as venues for the components to fight their battles. As such, institutional design is informed by the division of power among them rather than the functional logic. ${ }^{65}$ Similarly, historical institutionalists and constructivists suggest an endogenous dynamic to institutional design and a quest for appropriate and legitimate institutions. ${ }^{66}$ In other words, the functionalist logic is only one explanation for international organizations. When surveying scholarship on UN design, most of the literature indeed does not take a functional perspective. ${ }^{67}$

A final issue that requires attention is the fact that this article has mainly dealt with periods of bureaucratic expansion. Since the mid-1990s, delegation has followed the continuous increase in deployments. The question to be raised is whether the functionalist logic will also hold during periods of decline. Will the UN Secretariat lose its resources once peacekeeping operations come to a close? Or are institutions simply difficult to reform? Moreover, it needs to be seen what the effects of the ongoing economic crisis are. States may be less inclined to sponsor peacekeeping operations, let alone the Secretariat resources that go with it. While this is difficult to predict, deployments may well go down in the next few years, testing the functionalist argument of this article. If the resources of the Secretariat stay constant in a period of decline in deployments, it may be necessary to settle for a 'domain of application' approach to delegation, in which the functional logic only explains institutional creation and growth. ${ }^{68}$

\section{ACKNOWLEDGEMENTS}

The author would like to acknowledge Raymond Montizaan, Arjan Schakel, Hans Schmeets, Sophie Vanhoonacker, and anonymous referees. The article was originally submitted when the author worked at Maastricht University, The Netherlands.

\section{NOTES}


1 This figure is for the professional and higher grades only.

2 This article is concerned with delegation by states to the UN Secretariat. Extensive delegation also takes place to peacekeeping missions in the field, which is beyond the scope of the article.

3 Michael Doyle and Nicholas Sambanis, Making War and Building Peace: United Nations Peace Operations, Princeton, NJ: Princeton University Press, 2006.

4 Mark Pollack, 'Delegation, agency, and agenda-setting in the European Community', International Organization, Vol.51, No.1, 1997, pp.99-134; Pollack, The Engines of European Integration: Agency, Delegation, and Agenda Setting in the EU, Oxford: Oxford University Press, 2003; Jonas Tallberg, 'Delegation to Supranational Institutions: Why, How, and with What Consequences?', West European Politics, Vol.25, No.1, 2002, pp.23-46; Darren Hawkins, David Lake, Daniel Nielson and Michael Tierney (eds), Delegation and Agency in International Organizations, Cambridge: Cambridge University Press, 2006. Curtis Bradley and Judith Kelley, 'The Concept of International Delegation', Law and Contemporary Problems, Vol.71, No.1, 2008, pp.1-36. There is a difference between delegation to international organizations and delegation within international organization. States delegate peacekeeping missions to the UN; within it they delegate functions to the Security Council, Secretariat, President of the General Assembly and so on. Frank Biermann and Bernd Siebenhüner (eds), Managers of Global Change: The Influence of International Environmental Bureaucracies, Cambridge, MA: M.I.T. University Press, 2009; Bob Reinalda and Bertjan Verbeek (eds), Decision Making Within International Organizations, London: Routledge, 2004.

5 Tallberg (see n.4 above), p.25.

$6 \quad$ Ibid., p.37.

7 UN DPKO and DFS, 'United Nations Peacekeeping Operations: Principles and Guidelines', New York, Jan. 2008, p.49; European Union, 'EU Concept for Military Planning at the Political and Strategic Level', 10687/08, Brussels, 2008, paras.6-7.

8 Hawkins (see n.4 above).

9 Kenneth Abbott and Duncan Snidal, 'Why states act through formal international organizations', Journal of Conflict Resolution, Vol.42, No.1, 1998, pp.3-32. Peacekeeping scenarios are, of course, never completely neutral, but the Secretariat has to take the preferences of all states into account.

10 Samuel Huntington, The Soldier and the State: The Theory and Politics of Civil-Military Relations, Cambridge, MA: Harvard University Press, 1957.

11 Anthony Rice, 'Command and Control: The Essence of Coalition Warfare', Parameters, Vol.27, No.1, 1997, pp.152-67.

12 Philip Cunliffe, 'The politics of global governance in UN peacekeeping', International Peacekeeping, Vol.16, No.3, 2009, pp.323-36; Michael Lipson 'Performance under ambiguity: International organization performance in UN peacekeeping', Review of International Organization, Vol.5, No.3, 2010, pp.249-84.

13 Bradley (see n.4 above); Oona Hathway, 'International Delegation and Domestic Sovereignty', Law and Contemporary Problems, Vol.71, No.1, 2008, pp.115-50; David Lake and Matthew McCubbins, 'The logic of delegation to international organizations', in Hawkins (see n.4 above), p.343.

14 David Epstein and Sharyn O'Halloran, 'Sovereignty and Delegation in International Organizations', Law and Contemporary Problems, Vol.71, No.1, 2008, p.82.

15 Kenneth Abbott and Duncan Snidal, 'Hard and Soft Law in International Governance', International Organization, Vol.54, No.3, 2000, p.437.

16 Michael Spence and Richard Zeckhauzer, 'Insurance, information, and individual action', American Economic Review, Vol.61, No.2, 1971, pp. 380-87; Gary Miller, 'The Political Evolution of Principal-Agent Models', Annual Review of Political Science, Vol.8, 2005, pp. 203-25.

17 Paul Pierson, 'The Path to European Integration: A Historical Institutionalist Analysis', Comparative Political Studies, Vol.29, No.2, 1996, pp.123-63; Paul Pierson, Politics in Time: History, Institutions and Social Analysis, Princeton, NJ: Princeton University Press, 2004.

18 Fritz Scharpf, 'The Joint-Decision Trap: Lessons from German Federalism and European Integration', Public Administration, Vol.66, No.3, 1988, pp. 239-78; George Tsebelis, Veto players: How political institutions work, 
Princeton, NJ: Princeton University Press, 2002; Nielson (see n.4 above); Randall Stone, Controlling Institutions: International Organizations and the Global Economy, Cambridge, MA: Cambridge University Press, 2011.

Hawkins (see n.4 above).

20 Lake (see n.14 above).

21 One can also study the number of deployed troops as a dependent variable. This is, however, a different research question (see n.4 above).

22 Data from 19 individual months from the periods 1990-92 and 1999-2001 are missing.

23 Data on 1990-92 have been estimated on the basis of UN Secretary-General, 'Comprehensive Review of the Whole Question of Peace-keeping Operations in all their Aspects', UN doc., A/46/169, 10 May 1991 and William Durch (ed.), The Evolution of UN Peacekeeping: Case Studies and Comparative Analysis, Washington DC: Henry L. Stimson Center, 1993. These reports include permanent staff members and officials paid through the Support Account for Peacekeeping.

24 The recruitment delay supports such causality. The section on process-tracing provides further evidence for causality.

25 Robert McClure and Morton Orlov, 'Is the UN Peacekeeping Role in Eclipse?', Parameters, Vol.29, No.3, 1999, pp.96-105. See further section on process-tracing.

26 Since these are not resources formally delegated to the Secretariat, they have been excluded in the analysis. Moreover, there is no precise data on gratis personnel per year to integrate them into the analysis.

27 New York University Center on International Cooperation, 'Building on Brahimi: Peacekeeping in an era of strategic uncertainty', New York, April 2009, p.42.

28 Thant Myint-U and Amy Scott, 'The UN Secretariat: A Brief History', International Peace Academy, New York, 2007.

29 The UN members are conceptualized as a collective principal (Nielson see n.4 above) regardless of whether it is the General Assembly, Security Council or Special Committee on Peacekeeping Operations. Only when these bodies reach agreement, can functions and resources be delegated to the Secretariat. If states cannot agree, because divided on the question of sovereignty, for example, they will not be able to delegate. Outcomes therefore often resemble the lowest common denominator among states.

30 UN Secretary-General, 'An Agenda for Peace: Preventive diplomacy, peacemaking and peace-keeping', UN Doc., A/47/277-S/24111, 17 June 1992, paras 14-15.

31 UN Special Committee on Peace-keeping Operations, 'Comprehensive Review of the Whole Question of Peacekeeping Operations in all their Aspects', UN doc., A/46/254, 18 June 1991, para.55.

32 UN, 'Note by the President of the Security Council' UN doc., S/23500, 31 Jan. 1992, pp.2-4.

33 UN Special Committee on Peace-keeping Operations, 'Comprehensive Review of the Whole Question of Peacekeeping Operations in all their Aspects', UN doc., A/47/253, 4 June 1992, paras.23,67,69.

34 A/47/277 (see n.30 above), paras 50,52.

35 Thorsten Benner, Stephan Mergenthaler and Philipp Rotmann, The New World of UN Peace Operations: Learning to Build Peace?, Oxford: Oxford University Press, 2011; Myint U (see n.28 above).

36 Stanley Meisler, Kofi Annan: a man of peace in a world of war, Hoboken, NJ.: Wiley, 2007, p.67.

37 Benner et al., (see n.35 above).

38 McClure and Orlov (see n.26 above).

39 Ibid.

40 Silke Weinlich, '(Re)generating Peacekeeping Authority: The Brahimi Process', Journal of Intervention and Statebuilding, DOI: 10.1080/17502977.2012.655625. 
41 Lakhdar Brahimi et al., 'Report of the Panel on United Nations Peace Operations', UN doc., A/55/305-S/2000/809, 21 Aug. 2000.

42 UN Secretary-General, 'The Fall of Srebrenica', UN doc., A/54/549, 15 Nov. 1999; Ingvar Carlsson, Sung-Joo Han and Rufus Kupolati, 'Report of the Independent Inquiry into the actions of the United Nations during the 1994 genocide in Rwanda', UN doc., S/1999/1257, 16 Dec. 1999.

43 Jean-Marie Guéhenno, 'On the Challenges and Achievements of Reforming UN Peace Operations', International Peacekeeping, Vol.9, No.2, 2002, pp.69-80.

44 Brahimi et al. (see n.41 above), p.i.

45 Weinlich (see n.40 above).

46 Brahimi et al. (see n.41 above), p.xiii.

47 Ibid., table 4.1, paras.172-3,183, 197.

48 William Durch, Victoria Holt, Caroline Earle, Moira Shanahan, 'The Brahimi Report and the Future of UN Peace Operations', Henry L. Stimson Center, 2003, table 4; UN Secretary-General, 'Resource requirements for the implementation of the Report of the Panel on United Nations Peace Operations', UN doc., A/55/507/Add.1, 27 Oct. 2000; UN ACABQ, 'Implementation of the Report of the Panel on United Nations Peace Operations', UN doc., A/55/676, 8 Dec. 2000.

49 Brahimi et al. (see n.41 above), para.176.

$50 \quad$ Ibid., para. 197.

$51 \quad$ Ibid.: paras.68,70.

52 Durch, et al., (see n.48 above).

53 Ibid.

54 UN Secretary-General, 'Implementation of the recommendations of the Special Committee on Peacekeeping Operations', UN doc., A/60/640, 29 Dec. 2005, paras.2,5,18.

55 UN Secretary-General, 'Implementation of the recommendations of the Special Committee on Peacekeeping Operations', UN doc., A/61/668, 13 Feb. 2007, paras.6-16.

56 Ibid., paras. 11, 20-38

57 Richard Gowan, 'Floating Down the River of History: Ban Ki-moon and Peacekeeping, 2007-2011', Global Governance, Vol.17, No.4, 2011, pp.399-416. Gowan notes that this was Ban Ki-moon trying to establish his authority over DPKO, where his reforms were deeply unpopular.

58 Secretary-General (see n.55 above), paras13,55.

59 UN Secretary-General, 'Comprehensive report on strengthening the capacity of the United Nations to manage and sustain peace operations', UN doc., A/61/858, 13 April 2007, para.16, Add.1, p.3.

60 Ibid., para 20.

61 UN Secretary-General, 'Report on the comprehensive analysis of the Office of Military Affairs in the Department of Peacekeeping Operations', UN doc., A/62/752, 17 March 2008.

62 UN Secretary-General, 'Strengthening the capacity of the United Nations to manage and sustain peacekeeping operations', UN doc., A/63/702, 3 Feb. 2009.

63 Ronald Hatto, 'UN Command and Control Capabilities: Lessons from UNIFIL's Strategic Military Cell', International Peacekeeping, Vol.16, No.2, 2009, pp.186-98; Alexander Mattelaer, 'Europe rediscovers peacekeeping? Political and Military Logics in the 2006 UNIFIL Enhancement', Egmont Paper 34, Egmont Institute: 
Royal Institute for International Relations, Brussels, 2009.

64 Alexander Wendt, 'Driving with the rearview mirror: On the rational science of institutional design', International Organization, Vol.55, No.4, 2001, pp.1019-49.

65 John Mearsheimer, 'The False Promise of International Institutions', International Security, Vol.19, No.3, 1994/95, pp.5-49.

66 Pierson 2004 (see n.17 above); Wendt (see n.64 above).

67 Michael Lipson, 'Peacekeeping: Organized Hypocrisy?', European Journal of International Relations, Vol.13, No.1, 2007, pp.5-34; Lipson, 'Peacekeeping Reform: Managing Change in an Organized Anarchy', Journal of Intervention and Statebuilding, DOI: 10.1080/17502977.2012.655626; Julian Junk, 'Function Follows Form: The Organizational Design of Peace Operations', Journal of Intervention and Statebuilding, DOI: 10.1080/17502977.2012.655627.

68 Joseph Jupille, James Caporaso and Jeffrey Checkel, 'Integrating Institutions : Rationalism, Constructivism, and the Study of the European Union', Comparative Political Studies, Vol.36, No.7, 2003, pp.7-40. 